\title{
The Basic Law: A Fifty Year Assessment*
}

\author{
By Donald P. Kommers ${ }^{\dagger}$
}

\section{A. Introduction}

IN 1949, Germany embarked upon a fascinating constitutional experiment. In that year, with the consent of the three occupying powers, the United States, France, and Great Britain, German leaders in the western zone of occupation drafted a new constitution that created the Federal Republic of Germany (FRG). ${ }^{1}$ They called it the Basic Law (Grundgesetz) to highlight its provisional character. The more dignified term "constitution" (Verfassung) would be reserved for the time when Germany as a whole would determine its own future. Accordingly, the Basic Law, by its own terms, was to cease to exist on the day a reunited Germany replaced it with a real constitution freely adopted by all the German people. ${ }^{2}$

The Basic Law raised as many questions as it tried to answer. Could a newly minted constitutionmere words on paper-breathe new life into a people devastated by war? Would it serve as a framework of government? Would it promote respect for human rights and popular government? Would it foster internal political unity? And if the FRG were to reach the half-century mark-as it would in 1999- how much of its success would be attributable to the values, rights, and powers laid down in the Basic Law? No one would have dared to answer these questions in 1949. Now, however, on the Basic Law's fiftieth anniversary, we are able to confidently respond to most of them.

\section{B. The Original Document: Its Main Features}

The sixty-one men and four women who framed the Basic Law-in an assembly known as the Parliamentary Council—did so in the shadow of the Third Reich and in the presence of a Communist dominated East Germany. With these experiences burned into their souls, the sixty-five delegates, whose median age was fifty-five, proceeded to create a constitutional democracy that would rebuild the Rechtsstaat, secure political stability, protect human rights, and maintain peace. ${ }^{3}$

In reconstituting themselves as a free people, the framers did not-and could not-reject their own democratic tradition, one best represented in the Weimar Constitution of 1919. Many of its

\footnotetext{
*[Originally appeared as Donald P. Kommers, The Basic Law: A Fifty Year Assessment, 53 S.M.U. L. ReV. 477 (2000). Republished here with permission of the original publisher.]

${ }^{\dagger}$ Professor, University of Notre Dame Law School.

${ }^{1}$ See Final Communique on London Talks Regarding Germany, in Documents on the Creation of the German Federal Constitution (Civil Administration Division: Office of Military Government for Germany [U.S], Sept. 1, 1949) at 42 (June 1, 1948).

${ }^{2}$ See GRUNDGESETZ [GG] [BASIC LAw] art. 146, translation at http://www.gesetze-im-internet.de/englisch_gg/index.html.

${ }^{3}$ For accounts of the proceedings of the Parliamentary Council see Entstehungsgeschichte der Artikel des Grundgesetzes, 1 Jahrbuch des OfFentlichen Rechts (1951); Werner Sörgel, Konsensus und InTEREssen (Ernst Klett Verlag 1969); JoHN Ford Golay, The Founding of the Federal Republic of Germany (1958); Peter H. Merkl, The Origin of the West German Republic (1963). See also Erhard H.M. Lange, Die Würde der Menschen ist unantastbar: Der Parlamentarische Rat UND DAs GRUNDGESETZ (1993).
} 
individual rights, provisions, and institutional arrangements were taken over by the Basic Law. In important respects, however, the Basic Law also broke new ground. In broad outline, the gulf between Weimar and Bonn (now Berlin) represented a major shift from a popular democracy to a constitutional democracy, emphasizing limits on the exercise of political power and constraints on majoritarian political institutions. The most interesting parts of the Basic Law have to do with these limits and constraints. They make up what might be called Germany's "new constitutionalism."4

The cornerstone of the new constitutionalism can be found in an enforceable bill of rights. These rights include all the classical, civil, and political freedoms of the western political tradition, but they also include communal values - marriage, family, motherhood, and the right of parents to have their children exposed to religious education in the public schools ${ }^{5}$ - that the state is obligated to protect and promote. Together with the fundamental liberties of speech, association, and religion, the Basic Law confers a general right to "personal freedom" as well as a more specific right to "life and physical integrity." 6 These general rights of liberty, like several other guaranteed rights, may be limited by law; in no case, however "may the essence of a basic right be encroached upon."7 Overarching and informing all of these rights and values is the principle of human dignity, which the first article of the Basic Law declares "inviolable." In fact, Article 1 makes it the duty of "all state authority to respect and protect" human dignity at all times. ${ }^{8}$ In accentuating the primacy of human dignity and the state obligations that derive from it, the Basic Law-far more than the American Constitution-speaks in the language of responsibilities as well as rights.

In addition, the Basic Law lays down structural principles of political order. These include popular democracy, federalism, separation of powers, the rule of law, party competition, and certain principles of political obligation: ${ }^{9}$ democracy manifests itself in representative institutions; federalism in strong state governments and local self-government; separation of powers in the division of authority between the constitutional organs of the national government; rule of law in a judiciary independent of the executive and the legislature; party competition in open, free, and direct elections; and principles of political obligation in the ban on activities aggressively opposed to the values and principles of the constitutional order. Equally constitutive of this order is the principle of the social welfare state (Sozialstaat). ${ }^{10}$ Finally, and no less important, the Basic Law (in its original version) looked to a unified Germany while committing the Federal Republic to serving peace "as an equal partner in a united Europe."11

What differentiates these rights, values, and principles from previous German constitutions is their supremacy and permanence. The Basic Law represents the fundamental law of the nation. As such, it derives its authority directly from the people, but all governmental authority is in turn derived from the constitution. Accordingly, the Basic Law serves as the supreme law of the land; it is a binding document and, as several of its provisions attest, it controls the entire legal order, categorically rejecting Weimar's principle of parliamentary supremacy in all things. ${ }^{12}$ The Basic Law declares that its rights and values "shall bind the legislature, the executive, and the judiciary as directly enforceable law." ${ }^{3}$ To remove all doubt about this, the Basic Law provides a judicial remedy for any violation of a basic right and creates a powerful constitutional court to guard and protect the constitution as a whole. ${ }^{14}$

\footnotetext{
${ }^{4}$ Donald P. Kommers, German Constitutionalism: A Prolegomenon, 40 EMORY L.J. 837, 845-55 (1991).

${ }^{5}$ See GrundgesETz [GG] [BASIC LAW] arts. 6, 7(2).

${ }^{6} I d$. art. 2.

${ }^{7}$ Id. art. $19(2)$.

${ }^{8}$ Id. art. 1 .

${ }^{9}$ For a detailed discussion of the jurisprudence related to these principles, together with citations to relevant publications, see Klaus Stern, I Das Staatsrecht der Bundesrepublik Deutschland 555-871 (1984).

${ }^{10}$ See Hans F. Zacher, Das soziale Staatsziel, in I HANDbuch DES StAatSReChts DER BundeSREPUblik 1042-1112 (1987).

${ }^{11}$ See Grundgesetz [GG] [BASIC LAW] pmbl.

${ }^{12}$ See Grundgesetz [GG] [BAsic LAW].

${ }^{13} I d$. art. 1(3).

${ }^{14}$ See Grundgesetz [GG] [BASIC LAW].
} 
Besides its supremacy, the Basic Law establishes its core principles in perpetuity. They are permanent. Article 79(3), the so-called "eternity clause," bans any constitutional amendment that would affect or undermine the dignitarian principles of Article 1 or the basic structural principles of the constitutional order set forth in Article 20 (i.e., federalism, separation of powers, rule of law, and the social welfare state). Putting an eternity clause into a provisional constitution seemed jarringly incoherent. Nevertheless, the framers believed that the best way to safeguard human dignity and preserve the "democratic and social federal state," now and in the future, was to place certain principles of government beyond the capacity of the people to amend-in short, to freeze history. These principles include severe restrictions on anti-democratic activities, one of the most important of which is the Basic Law's prohibition of political parties seeking "to impair or abolish the free democratic basic order." 15

The political system created by the Basic Law was a bold experiment in constitutional engineering, designed above all to combine popular democracy with political stability. In short, the framers set out to correct the faults and close the loopholes believed to have contributed to Hitler's rise to power and Weimar's destruction in 1933. One major change was the Basic Law's lack of any reference to popular referenda or initiatives on national issues. A related change was the weakening of the office of president. Under Weimar's Constitution, the president of the Reich was elected by all the people and regarded as the embodiment of their will. He could dissolve parliament, dismiss the chancellor, exercise emergency powers, command the armed forces, suspend legislation, and submit laws to a referendum. ${ }^{16}$ Under the Basic Law, presidents can do none of these things, and they no longer compete with the chancellor in the exercise of governmental power. What is more, they are elected indirectly by a convention of state and federal parliamentary delegates and serve as relatively powerless and ceremonial heads of state.

The Basic Law lodges real executive power in the hands of the chancellor. It puts him in charge of the government and makes him its chief policymaker. Although the chancellor is elected by and responsible to parliament, parliament is unable to dismiss him unless it simultaneously elects his successor. This so-called "constructive vote of no-confidence" gives the chancellor considerable leverage over parliament. In the Weimar Republic, parliament could dissolve itself and trigger new elections, with the result that no parliament survived the full term for which it was elected. Under the Basic Law, by contrast, parliament may not dissolve itself. Members of parliament are elected for a fixed term of four years in universal adult suffrage. New elections can be held prior to the expiration of this four-year period only if the chancellor loses a vote of confidence that he initiates and then only if the federal president decides to call for new elections at his or her (i.e., the chancellor's) request. ${ }^{17}$ These arrangements help to account for the relative stability of German governments over the last fifty years.

In still another break with the past, the Basic Law recognizes political parties as major organs of parliamentary representation. On the other hand, Article 21(2) declares unconstitutional those parties "which by reason of their aims or the conduct of their adherents seek to impair or abolish the free democratic basic order." 18 This prohibition and related provisions of the Basic Law, such as Article 9's ban on associations directed against the constitutional order, establish what has come to be known as Germany's "guarded" democracy. It obliges the state to oppose persons and groups who would use their rights to subvert or destroy democracy. ${ }^{19}$ Whatever else may be said about

\footnotetext{
${ }^{15} I d$. art. 21(2).

${ }^{16}$ For the full text and discussion of the Weimar Constitution, see Democratic Tradition: Four German Constitutions 147-90 (Elmar Hucko ed., 1987).

${ }^{17}$ See GRUNDGESETZ [GG] [BASIC LAw] art. 68. This procedure has been used only twice in the Federal Republic's history, first by Willy Brandt in 1972 and then by Helmut Kohl in 1983. In each instance, the chancellor engineered his defeat in the hope that new elections would increase his parliamentary majority. The strategy worked for both chancellors.

${ }^{18} I d$. art. $21(2)$.

${ }^{19}$ See Jürgen Becker, Die wehrhafte Demokratie des Grundgesetzes, in VII HANDBUCH DES STAATSRECHTS DER Bundesrepublik 309 (1992); Donald P. Kommers, The Constitutional Jurisprudence of the Federal Republic of
} 
these provisions, they certainly dampen, as the framers intended, popular pressures for revolutionary reform.

Germany's electoral system is both a reflection, as well as a determinant, of its party system. In setting up an electoral system, the framers returned to Weimar's system of proportional representation, but with a difference. They adopted a two-ballot system that combined single-member districts with proportional representation, along with the rule that bars legislative representation to political parties failing to get at least five percent of the national vote, a rule designed to rid Germany of the splinter parties that undermined effective parliamentary government in the Weimar Republic. ${ }^{20}$ Neither the electoral system, nor the five percent rule is specified in the text of the Basic Law. But, their solid anchorage in German electoral law (both state and federal) since 1949 , and their canonical status in the jurisprudence of the Federal Constitutional Court, has virtually elevated proportional representation and the five percent rule into established constitutional practices. ${ }^{21}$

Perhaps the most daring institutional innovation of the Basic Law is the creation of the Federal Constitutional Court, a judicial tribunal empowered to resolve constitutional disputes between branches and levels of government and to review the constitutionality of federal and state law. As the guardian of the Basic Law, the Court was designed to serve as the umpire of the federal system, the custodian of party democracy, and the protector of all guaranteed values and rights. ${ }^{22}$ In short, Germany's older parliamentary democracy had been transformed into a new juridical democracy, solidifying the Rechtsstaat by keeping popular majorities from exceeding the limits of the constitution.

\section{A Too Flexible Constitution?}

John Marshall, the great Chief Justice of the United States Supreme Court, once remarked that a constitution by its nature "requires that only its great outlines should be marked [and] its important objects designated." ${ }^{23}$ He later sharpened the point by saying that "a constitution is designed to approach immortality as nearly as human institutions can approach it." ${ }^{24}$ In measuring the Basic Law against these standards, we confront a document far less lapidary than our description of the new constitutionalism might suggest. In its original form, the Basic Law consisted of a preamble and 146 articles, 151 if we include the five articles of the Weimar Constitution on churchstate relations absorbed into the Basic Law under Article 140. At least sixty of these articles dealt directly or indirectly with federal-state relations. The detail in these provisions is as much a result of Allied insistence on constitutionalizing the rights of the states in the fields of tax policy and public administration as of any German penchant for precision and thoroughness.

By 1999, the Basic Law had ballooned into a document of 181 articles-185 if we again include the Weimar religious articles. It had been amended forty-six times, almost one major amending act per year, introducing changes into 58 articles and 110 paragraphs of the original constitution. ${ }^{25}$ Over and above these changes, 41 new articles were put into the constitution, 21 paragraphs and clauses, of which were in turn amended or repealed in subsequent years. These 41 articles are

\footnotetext{
Germany 217-37 (1997). See also Judith Wise, Dissent and the Militant Democracy: The German Constitution and the Banning of the Free German Workers Party, 5 U. CHI. L. SCH. Roundtable 301 (1998).

${ }^{20}$ For a comprehensive study of the German electoral process, see Uwe Kitzinger, GeRman ElECTORAL Politics: A STUdy OF THE 1957 CAMPAign (1960).

${ }^{21}$ See Kommers, supra note 19 , at 181-96.

${ }^{22}$ For a general discussion of the status, proceedings, and decisions of the Federal Constitutional Court, see KLAUS SCHLAiCH, DAs BundesverfassungsGericht (1991).

${ }^{23}$ McCulloch v. Maryland, 17 U.S. (4 Wheat.) 316, 407 (1819).

${ }^{24}$ Cohens v. Virginia, 19 U.S. (6 Wheat.) 264, 387 (1821).

${ }^{25}$ For a list of all amendments to the Basic Law and the articles, paragraphs, and clauses affected thereby, see ANGELA BAUER \& Matthias Jestaedt, Das Grundgesetz im Wortlaut 53-65 (1997).
} 
about one-third the length of the original constitution. The United States Constitution, by contrast, had been amended a miserly seventeen times between 1791 and 1999, an average of one amendment every twelve years. The Basic Law was obviously not a perfect constitution. What constitution is?

A modern-day John Marshall would probably trace the Basic Law's imperfection to its preoccupation with detail, or to its failure to distinguish between what he called "great outlines" and "minor details." It is within the intent of a constitution, Marshall wrote, "to endure for ages to come, and consequently to be adapted to the various crises of human affairs."26

On the other hand, Americans should be slow to accept the Marshallian critique of the Basic Law. After all, we Americans, along with the British and the French, did not allow the Germans to adapt their constitution to the various crises of human affairs. It was not a document created for ages to come, but for a transitional period. It was a seasonal document quickly drafted under Allied pressure and in the face of mushrooming hostility between East and West. It was likewise the product of a divided and occupied Germany, reflecting the absence of sovereign nationhood and requiring transitional provisions on such matters as citizenship, refugees, elections, former Nazis, the status of Berlin, and the organization of the federal territory. Little wonder that the Basic Law would be in need of substantial amendment as West Germany gradually regained her national sovereignty. As time passed, it would be necessary to fill gaps and correct flaws in the original document. The transitional provisions just mentioned required some seventeen changes over the years.

\section{Maintaining the Constitution}

Most of the repair work on the Basic Law took place during the years 1954-56, 1968-69, and 199094. The first round of amendments adjusted the Basic Law to the restoration of West German sovereignty and remilitarization; the second round reflected the FRG's concern with internal and national security; the final round sought to harmonize the Basic Law with Germany's reunification and membership in the European Union. Each of these periods represented transformative moments in German constitutional politics. In addition, each round of amendments took place in legislative periods in which it was relatively easy to garner a two-thirds vote necessary to amend the Basic Law. In the first period (1953-57), the Adenauer-led coalition parties were at the top of their strength in both houses of parliament; in the second (1965-69), a grand coalition between Social and Christian Democrats ruled the country; in the third (1990-94), Germany reveled in the nation's reunification. The three rounds of changes affected, respectively, 24, 61, and 38 articles of the Basic Law.

\section{The First Round}

West Germany's first great constitutional debate opened with the Adenauer government's decision in 1952 to join the European Defense Community (EDC). ${ }^{27}$ Would the Basic Law permit Germany to establish a conscript army? The parliamentary opposition answered with an emphatic "no." Social Democrats and their supporters saw the Basic Law as a peaceful constitution, one born of the Allied decision to demilitarize Germany. They argued, correctly, that it conferred no explicit authority to build an army and banned any preparation for military aggression. In response, the government insisted that the "military aggression" clause conferred an implied power to create an armed force for defensive purposes. In 1954, after two years of debate, and

\footnotetext{
${ }^{26} \mathrm{McCulloch}, 17$ U.S. at 415.

${ }^{27}$ For a treatment of the events surrounding this debate, see Karl Loewenstein, The Bonn Constitution and the European Defense Community Treaties: A Study in Judicial Frustration, 64 Yale L.J. 805 (1955). See also Eckart Klein, Der innere Notstand, in VII HANDBUCH DES StAATSRECHTS DER BundesRePUblik 387, 390-405 (1992).
} 
following the 1953 election, all doubts about the legitimacy of Germany's membership in a defense alliance were removed. The government succeeded in amending the Basic Law to authorize the Federation to provide for the country's defense and a military draft. In 1956, finally, twelve additional articles were amended to meet the requirements of a defense establishment.

The dispute over rearmament was a major chapter in the constitutional politics of the FRG. It was also an important symbol of West Germany's commitment to constitutional governance and the rule of law. Unable initially to resolve the conflict politically, the parliamentary opposition, the government, and the Federal President took turns in petitioning the Federal Constitutional Court for a ruling on whether the FRG's membership in EDC would be constitutionally permissible. However, the 1954 amendments obviated the need for a judicial ruling. What is important for present purposes is that all sides in the dispute accepted the supremacy of the Basic Law and, equally significant, the legitimate role of the Federal Constitutional Court in its interpretation. This was an encouraging sign for the future development of German constitutionalism.

\section{The Second Round}

The years 1968 and 1969 actually represented successive waves of constitutional change, the first centering on procedures for declaring and managing a national emergency, the second on domestic policy concerns and the federal-state relationship. The 1968 emergency amendments, which added sixteen new articles to the document and repealed three old ones, ${ }^{28}$ extended the powers of the Federation to pass bills, issue directives, and take other measures to meet a foreign invasion or major civil disturbance. What is interesting about these new provisions is the meticulous care taken by their authors to limit the duration of any emergency, to require the Bundesrat's consent to emergency measures passed by the Bundestag, and to curtail civil liberties no more than necessary. In fact, Article 115(g) provides that the powers and functions of the Federal Constitutional Court may not be set aside or changed during a state of emergency. To this extent, the changes in the Basic Law gave way to German critics who regarded the emergency amendments as a license for governmental oppression and dictatorship.

Fierce opposition greeted the emergency amendments when originally debated, triggering violent street demonstrations and other forms of unrest. ${ }^{29}$ The broader context of German politics helps to explain the opposition. The mid-to-late $1960 \mathrm{~s}$ were transitional years in German politics. A cultural revolution was in the making. Universities were under siege. The Cold War was heating up. Anti-Americanism, spawned by the Vietnam War, was on the rise, and anti-militarism was one of its consequences. ${ }^{30}$ In the mind of its critics, moreover, Bonn's grand coalition (1966-69) subverted the democratic process by virtually eliminating an effective parliamentary opposition. The result was the birth of an extra-parliamentary "New Left" movement that would grow in numbers and stridency in the years ahead.

The 1969 wave, on the other hand, followed the end of the grand coalition, marking still another turning point in Germany's constitutional development. Helped by the "New Left" movement, the Social Democratic Party (SPD), led by Willy Brandt, came to power in Bonn for the first time in the postwar period. The constitutional emphasis now shifted to the domestic scene. Two amending acts affecting some twenty articles of the Basic Law dealt mainly with budgetary and fiscal affairs, reaffirming and concluding West Germany's emancipation from all Allied dictates over the relationship between the federation and the states. Constitutional changes awarded new powers to the federation over the field of higher education, loosened certain restrictions on budgetary planning, modified guidelines for the apportionment of tax revenues among levels of

\footnotetext{
${ }^{28}$ See table of amendments and subsequent changes in the text of the Basic Law in BAUER \& JESTAEDT, supra note 25, at $53-65$.

${ }^{29}$ See Dennis L. Bark \& David R. Gress, Democracy and Its Discontents 1963-1991 120-21 (1993).

${ }^{30}$ See id. at $121-36$.
} 
government, and conferred discretionary instead of mandatory authority on the Federation to modify state boundary lines. In short, the authors of these amendments had realigned the federal-state relationship in favor of more power at the center and in conformity to perceived social and economic needs. ${ }^{31}$

The trend toward constitutionalizing central legislative power continued in the $1970 \mathrm{~s}$. Additional amending acts during these years expanded the federation's authority over several domestic policy areas, the most controversial of which was police activity. The political turmoil that started with the emergency amendments of 1968 had not subsided, and internal security remained high on the constitutional agenda. Accordingly, the Basic Law was amended to authorize a greater federal role in police investigation, ${ }^{32}$ in compiling data on subversive activity, ${ }^{33}$ in securing the loyalty of public servants, ${ }^{34}$ and in controlling commerce in weapons and explosives. ${ }^{35}$

The internal security amendments were deemed necessary to combat domestic terrorism as well as less dangerous forms of anti-state activity. Several other amendments, however, expanded West Germany's democracy and reinforced political accountability. They did so by lowering the voting age to eighteen, ${ }^{36}$ by requiring political parties to publicly account for the uses (as well as the sources) of their funds, ${ }^{37}$ and by providing for a parliamentary petitions committee to hear the complaints of ordinary citizens. ${ }^{38}$ These changes supplemented a 1969 amendment that conferred a constitutional right on all persons to file individualized complaints with the Federal Constitutional Court to vindicate their guaranteed rights against any interference by the state. ${ }^{39}$ The Basic Law had changed in substantial ways to meet the needs of internal security, but it was also amended to reinforce its underlying principles of democracy and Rechtsstaatlichkeit.

\section{The Third Round}

The extension of the Basic Law to the five new Länder of the old German Democratic Republic (GDR) required considerable constitutional surgery, and the Unity Treaty wielded the scalpel. We may pass over amendments that repealed Article 23 (extending the Basic Law's reach to new territories) and expunged all other references in the Basic Law to the goal of unity or the recovery of other lost German territory. Article 23's repeal effectively froze Germany's present borders, legally foreclosing any further claims to territory lost in World War II. We may also pass over changes required in the structure of the Bundesrat as well as an article temporarily releasing the new Länder from obedience to certain constitutional provisions. More important for present purposes are treaty provisions amending Article 146 and recommending future changes in the Basic Law, ${ }^{40}$ matters taken up below in the discussion of constitutional reform.

A series of amendments passed in 1993 and 1994 brought the Basic Law into accord with the Maastricht Treaty on European Union, expanded the authority of the federation over new activities and operations, clarified the rights of the Länder in European affairs, and enlarged their powers of consent in the Bundesrat. The most significant of these changes was a new sevenparagraph Article 23 permitting the transfer of sovereign power to the European Union. A related

\footnotetext{
${ }^{31}$ BAUER \& JESTAEDT, supra note 25 , at 57-60.

${ }^{32}$ See GrundGESETZ [GG] [BASIC LAw] arts. 73(10), 87(1) (1972).

${ }^{33}$ See id. art. 87(1).

${ }^{34}$ See id. art. 74a (1971).

${ }^{35}$ See id. art. 74(4a) (1972).

${ }^{36}$ See id. art. 38(2) (1970).

${ }^{37}$ See id. art. 21(1) (1983).

${ }^{38}$ See id. art. 45(c) (1975).

${ }^{39}$ See id. art. 93(1) [4a] (1969).

${ }^{40}$ See Donald P. Kommers, The Basic Law Under Strain: Constitutional Dilemmas and Challenges, in CHRISTOPH ANDERSEN \& Karl Kaltenthaler, Domestic Politics of German Unification 135-54 (Wolfgang Luthardt ed., 1993). See also Donald P. Kommers, The Basic Law and Reunification, in The Federal Republic of Germany at Forty-Five 187-204 (Peter Merkl ed., 1995).
} 
change in Article 88 authorized the Federal Bank to transfer its responsibilities and powers to the European Central Bank. Another amendment conferred on foreign nationals of the European Union the right to vote in local elections, ${ }^{41}$ a change that reversed a decision of the Federal Constitutional Court invalidating the right of non-citizens to vote in such elections. ${ }^{42}$

Other amendments in the $1990 \mathrm{~s}$ authorized the privatization of the railroads, air transport, postal services, and other operations directly administered by the Federation. The national government's power was also expanded to include concurrent jurisdiction over genetic engineering and human transplants, not to mention new authority to lay down guidelines for preventing the transfer abroad of cultural property. It is worth noting that nearly every major extension of the Bundestag's legislative authority was accompanied by provisions requiring the Bundesrat's consent to the exercise of such authority. Article 20(a), a new provision, contained a directive requiring the state to protect "the natural sources of life." Still other changes reallocated tax revenue, modified legislative procedures, and authorized state boundary changes. ${ }^{43}$

\section{E. Change and Continuity}

Constitutional change in the Federal Republic shows that the Basic Law had been transformed into a document very different from the version adopted by the Parliamentary Council in 1949. A modern-day John Marshall might say that the difference is in the details or "minor ingredients." He might suggest that the Basic Law has been distended into an unwieldy bulk that mocks the contrast between triviality and fundamentality. Indeed, he could point out that fifty percent of all constitutional changes in the written document modified the minutiae of sections dealing with public administration, court organization and jurisdiction, taxation and public finance, a state of emergency, and transitional provisions. But, this all too American perspective overlooks and ignores the culture of the German Rechtsstaat, a culture that requires, in deference to the rule of law, that legal documents provide as much guidance as possible to their interpretation by the judiciary and other government agencies.

The three rounds of constitutional amendments are equally important for what they have not changed. In particular, they have not touched the fundamental principles and structures of the Basic Law. Democracy, federalism, separation of powers, the rule of law, the Sozialstaat, and the multiparty state have remained largely undiminished. Their integrity, moreover, can be said to have been enhanced by the decisions of the Federal Constitutional Court. Also largely untouched by amendments were the Basic Law's sections on parliament, Bundesrat, federal presidency, chancellor and cabinet, and the Federal Constitutional Court, each of which is a major constitutional organ of the Federal Republic. Even the twenty-nine textual changes in the section on federal legislative powers failed to alter the essential character of German federalism, ${ }^{44}$ as the increasingly important role of the Bundesrat tended to show.

\footnotetext{
${ }^{41}$ See GRUNDGESETZ [GG] [BASIC LAw] art. 28(1) (1992).

${ }^{42}$ See Bundesverfassungsgericht [BVERFG] [Federal Constitutional Court] Oct. 31, 1990, 83 EnTSCHEIDUNGEN DES BUNDESVERFASSUNGSGERICHTS [BVERFGE] 37, 1990 (Ger.).

${ }^{43}$ See BAUER \& JESTAEDT, supra note 25 , at 62-64.

${ }^{44}$ Some observers would disagree with this view. The original version of the Basic Law conferred numerous and important powers on the states. Developments over the years eroded many of these powers, however. By the $1960 \mathrm{~s}$, the Federal Republic was described as a unitary (unitarische) federal state, i.e., one with strong centralizing features. By the early $1970 \mathrm{~s}$, it was also characterized as a system of cooperative federalism, and, by the late $1970 \mathrm{~s}$, as a system of Politikverflechtung, a complex form of joint decision making among many centers of power and influence. Many commentators came to believe that federalism, despite the eternity clause, had become a facade for an increasingly centralized state, especially in regard to public finances, and that the states had lost much of their relevance as legislative bodies. This assessment is flawed, however. In spite of certain losses of power by the states, they remain important political and administrative units in a relatively decentralized governmental system, particularly in view of recent constitutional amendments requiring the Bundesrat's consent to European policies affecting vital local interests.
} 
More serious were the textual changes in the Bill of Rights (Articles 1-17). But even here, nine of the original seventeen articles that protect fundamental rights remain unamended. These include the general right to "personal freedom" as well as the more specific right to "life and physical integrity." 45 The unamended articles also include those guaranteeing freedom of religion, ${ }^{46}$ freedom of speech, ${ }^{47}$ freedom of assembly, ${ }^{48}$ and the right to property, ${ }^{49}$ along with articles providing for the protection of marriage and family ${ }^{50}$ and parental rights in education. ${ }^{51}$ Eight articles of the Bill of Rights, however, have been altered in some fashion. By contrast, the American Bill of Rights has never been amended. Amendments to four of these articles actually expanded the guaranteed right affected, ${ }^{52}$ whereas several other changes adjusted the Bill of Rights to remilitarization and emergency defense requirements. But, any emergency justifying a limitation on a guaranteed right would have to be declared by the Bundestag and consented to by the Bundesrat, a significant political protection against any arbitrary invasion of a basic liberty. Article 12(a), the result of remilitarization, actually secured the right to refuse military service involving armed combat, but it required conscientious objectors to perform alternative service.

Amendments that caused the most alarm among German civil libertarians restricted the right of privacy and the right to asylum. Articles 10 and 13 secured the inviolability, respectively, of the secrecy of the mails and of the home. The former was amended in 1968, to allow interferences with private communications, without the knowledge of the affected parties, when necessary to protect the free democratic order; the second was amended in 1998 to allow law enforcement agencies to employ electronic surveillance when they suspect serious criminal activity that endangers individuals or the public. Did these amendments encroach on the "essence" of a basic right in violation of Article 19(2)? As for Article 10, the Federal Constitutional Court said "no" even in the face of the provision that barred judicial review of restrictions on private communications. ${ }^{53}$ The Court's 5-3 decision struggled to reconcile the principle of human dignity with the need for Germany's "guarded democracy" to protect itself against foreign and domestic enemies. Whether these amendments were necessary to achieve their stipulated ends is an open question. After all, the rights guaranteed in Articles 10 and 13, like many basic rights, are subject to limitation by ordinary laws, and these laws in turn are subject to judicial review.

The third amendment (Article 16(a), ratified in 1993) seriously qualified the right to asylum. The original right was a powerful expression of Germany's political morality in the light of the nation's past. It granted an absolute right to asylum to all persons persecuted on political grounds. In the early $1990 \mathrm{~s}$, however, hundreds of thousands of asylum seekers were clamoring at the nation's gates, causing severe pressures on the domestic economy and on administrative courts. Article 16(a) was designed to deal with this problem; it limits the former unlimited right in part by making neighboring countries responsible for handling asylum claims. An asylum claimant can now be held up at an international airport if he or she has not sought asylum in certain neighboring countries. ${ }^{54}$ Although the subject of enormous controversy, the new article had no impact on the rights of German citizens or resident aliens. The right to asylum was cut back substantially, but

\footnotetext{
${ }^{45}$ See GRUNDGESETz [GG] [BASIC LAW] art. 2 (2000).

${ }^{46}$ See id. art. 4.

${ }^{47}$ See id. art. 5.

${ }^{48}$ See id. art. 8.

${ }^{49}$ See id. art. 14.

${ }^{50}$ See id. art. 6.

${ }^{51}$ See GrundGesetz [GG] [BASIC LAW] art. 7.

${ }^{52}$ See Grundgesetz [GG] [BASIC LAw] art. 1(3) (1956); GRundGESETZ [GG] [BASIC LAW] art. 3a (1994); GRUNDGESETZ [GG] [BASIC LAW] art. 9(3) (1968); GRUNDGESETZ [GG] [BASIC LAW] art. 12 (1968).

${ }^{53}$ See Bundesverfassungsgericht [BVERFG] [Federal Constitutional Court] Dec. 15, 1970, 30 EnTSCHEIDUNGEN DES BundesVERFASSUNGSGERICHTS [BVERFGE] 1, 1970 (Ger.).

${ }^{54}$ See Bundesverfassungsgericht [BVERFG] [Federal Constitutional Court] May 14, 1996, 94 ENTSCHEIDUNGEN DES Bundesverfassungsgerichts [BVerfGE] 49, 1996 (Ger.) (reporting Federal Constitutional Court decision upholding this policy).
} 
most commentators regarded it less as a German than a European problem that would have to be resolved by European institutions.

In short, while the German constitution changed in substantial ways over the years, the changes did not erode the essential nature of the constitution as a charter of limited government and individual rights. Some amendments may have posed potential threats to civil liberties, but in each case, the Federal Constitutional Court handed down rulings curtailing abuses arising from them. The Court has not only been an effective instrument in protecting the essence of basic rights, it has also played a significant role in adapting the constitution to changing conditions. At the end of the day, these judicial adaptations seem more important than formal constitutional amendments. The Constitutional Court has been at the epicenter of Germany's system of government- the Basic Law put it there-influencing the shape of its politics, guarding its institutions, circumscribing its powers, promoting the constitution's political morality, and securing the effective enjoyment of basic rights. ${ }^{55}$ What is more, the record of official compliance with the court's decisions, even in highly controversial cases, has been extraordinary. To this extent, Germany's Rechtsstaat continues to thrive.

\section{F. Constitutional Reform}

The last fifty years have been punctuated by decennial evaluations of the Basic Law and occasional calls for its total revision. ${ }^{56}$ The evaluations led to few, if any, changes, and all appeals for major constitutional revision have been rejected. By 1989, most commentators believed the Basic Law had survived the test of time. The institutions it created were functioning pretty much as planned. Stability and peace had been accomplished under its auspices. The Rechtsstaat and the Sozialstaat coexisted in relative harmony. Civil liberties were generally respected and jealously guarded by the courts, as the decisional law of the Federal Constitutional Court demonstrates. Meanwhile, the Constitutional Court had created a legacy fully comparable in volume and sophistication to the postwar jurisprudence of the United States Supreme Court. This legacy included four decades of constitutional scholarship, as voluminous as it was distinguished. In short, a growing and vibrant constitutional tradition had been created, infusing the Basic Law with the character of a document framed to last in perpetuity.

Then the unanticipated happened. Germany reunified, offering 64 million West Germans and 16 million East Germans a chance to reconstitute themselves as a people under a new, or at least substantially revised, constitution. The Unity Treaty itself held out hope of major constitutional change. It instructed the soon-to-be-chosen all-German parliament to have the Basic Law reviewed in the light of national unity and to consider submitting it, at long last, to a popular referendum. In fact, the treaty retained the Basic Law's contingent status. Although it declared the Basic Law valid for the entire nation, it kept the language of Article 146 calling for its termination when the German people freely adopt a new constitution. ${ }^{57}$

Parliament made good on the promise to review the Basic Law. It established a sixty-four member legislative commission on constitutional revision comprised of an equal number of members from the Bundestag and Bundesrat. Over a period of fifteen months (from January 1992 to March 1993), the joint commission solicited and considered proposals for constitutional renewal from a wide circle of governmental and non-governmental sources, including dozens of constitutional scholars. Hundreds of proposals were received, seeking mainly to realign the federal-state relationship, to grant more autonomy to local communities, to incorporate state objectives into

\footnotetext{
${ }^{55}$ See Kommers, supra note 19; David Currie, The Constitution of the Federal Republic of Germany (1994).

${ }^{56}$ See Paul KirchHof, Brauchen wir ein erneuertes Grundgesetz (1992).

${ }^{57}$ The new version reads: "This Basic Law, which since the achievement of the unity and freedom of Germany applies to the entire German people, shall cease to apply on the day on which a constitution freely adopted by the German people takes effect." GRUNDGESETZ [GG] [BASIC LAW] art. 146.
} 
the Basic Law, to introduce social and economic rights, and to open the political system to more citizen participation, including the adoption of initiatives and referenda at the federal level. Perhaps the most favored of all proposals was the submission of the Basic Law itself to a popular referendum.

Nearly all these recommendations were rejected, including the referendum on the Basic Law. ${ }^{58}$ Constitutional changes that won the joint commission's approval included several provisions authorizing Germany to participate in the European Union. As noted earlier, they also included a new amendment obliging the state to protect the environment. Egalitarian impulses from East and West Germany, particularly among women's groups, resulted in an amendment to Article 3, paragraph 2, which in its original version secures equal rights to men and women. A new sentence authorizes the state to adopt measures for doing away with existing inequalities between men and women. Another change added "physical disability" to the list of forbidden legislative classifications under paragraph 3.

The defeat of proposals to introduce methods of direct democracy was a major letdown for persons appalled and disillusioned by what they regarded as an increasingly frozen political system governed by entrenched elites and ossified party structures. The joint commission did not wish to modify the representational character of Germany's political order. Nor did the commission see any value in proposals to allow parliament to dissolve itself or to abolish the five percent clause governing federal and state elections. Constitutional experts inside and outside parliament felt that such changes would pose the danger of fragmenting the electorate and thus undermine the stability and balance that constitutional arrangements adopted in 1949 were designed to secure.

\section{G. Conclusion}

The questions posed at the beginning of this essay can, for the most part, be answered in the affirmative. The Basic Law has served as a relatively stable framework of government: it has resulted in the effective realization of human rights; it has served as a rallying cry for Germany's reunification; and it has contributed to the growth of German democracy. All the major elements of a modern large-scale democracy are present. These include parliamentary representation; free, fair, and frequent elections; freedom of expression; sources of information not under governmental control; and a civil society made up of independent associations and interest groups. This is not to say that German democracy is perfect. It is imperfect, as are all existing democracies. It is sufficient to suggest that German democracy is as durable and stable as any other long-lasting democracy in the western world.

Whether the Basic law is the principal cause of Germany's stability and durability over the last fifty years is a harder question. It has often been said that German democracy owes its success to peace and prosperity. There is little doubt that social and economic conditions have been highly favorable to the stability of Germany's democratic institutions. But, it would be foolhardy at this late date to suggest that the Basic Law has not had a significant influence on the development of Germany's constitutional democracy. We lack exact measurements of the Basic Law's influence, but this uncertainty should not obscure the fact that German democracy would look differently if it were not for the normative principles and constitutional arrangements prescribed by it.

What does seem certain is the constitution's influence on German public attitudes. The constitution's legitimacy is no longer contested, even by those who would liked to have seen the Basic Law ratified in a popular referendum. Obscured by popular indifference in the early $1950 \mathrm{~s}$, the Basic Law has emerged as the vital center of Germany's constitutional culture. It is invoked repeatedly in parliamentary debates and resorted to in litigation by parties and politicians of all colors, which is one sign of the unity and integration it has managed to produce. It has guided multiple transformations in the country's political and social life; by any standard, it has been as adaptable

\footnotetext{
${ }^{58}$ See Helga-Lothar Batt, Die Grundgesetzreform NaCh Der deutschen Einheit (1996).
} 
to change as it has been successful in maintaining democracy and the rule of law. In fact, the Basic Law has evolved into one of the world's most respected and imitated constitutions. This alone is a major achievement that could not have been realized without the success the Basic Law has enjoyed in Germany.

The Basic Law's success is in no small measure owing to the institution of constitutional review and the work of the Federal Constitutional Court. Indeed, the constitution's fundamentality has been reinforced by fifty years of authoritative interpretation and scholarly commentary, overlaying the Basic Law with the silver plates of both permanence and esteem. In saying this, we need to emphasize once again that the Basic Law is not perfect. This essay has pointed out several of its imperfections, not the least of which is its prolixity and the relative ease with which it can be amended. Constitutional politics should not be confused with ordinary politics. This is a distinction that frequency of amendment often overlooks. Many of the minor ingredients of the Basic Law could well be eliminated without doing any damage to its integrity as the fundamental law of the nation.

When Benjamin Franklin emerged from the American constitutional convention in 1789, he was asked what kind of government had been created. He replied, "A republic if you can keep it." Fifty years later, in 1839, in a discourse delivered at the request of the New York Historical Society, John Quincey Adams, the sixth President of the United States, was able to report that the Constitution had indeed survived the test of time and that "its results have surpassed the most sanguine anticipations of its friends." The same judgment could be made about the Basic Law in 1999, fifty years after its birth.

Cite this article: Kommers DP (2019). The Basic Law: A Fifty Year Assessment. German Law Journal 20, 571-582. https:// doi.org/10.1017/glj.2019.48 